\title{
Ownership and market entry mode choices of emerging country multinationals in a transition country: evidence from Turkish multinationals in Romania*
}

\author{
Ibrahim Anil, Ekrem Tatoglu, Gaye Ozkasap ${ }^{* *}$
}

Drawing upon key arguments of prevailing theoretical perspectives in international business, this study aims to explain the ownership and market entry strategies of emerging country multinational enterprises (MNE) in a transition country. To this end, the Turkish MNEs' ownership (joint venture versus wholly owned subsidiary) and entry mode (greenfield versus acquisition) choices for their affiliates in Romania are essentially investigated based on a number of selected case studies. Using qualitative data from semi-structured interviews, this study indicates that a single perspective alone cannot adequately explain the Turkish MNEs' ownership and entry mode strategies for their affiliates in Romania.

Aufbauend auf Schlüsselargumenten der vorherrschenden theoretischen Perspektiven im internationalen Geschäft, zielt diese Studie auf die Erklärung der Eigentums- und Markteintrittsstrategien von multinationalen Unternehmen (MNU) noch unterentwickelter Länder in einem Transformationsland. Zu diesem Zweck wurde hauptsächlich die Wahl des Eigentumsverhältnisses (Joint Venture versus hundertprozentige Tochtergesellschaft) und des Eintrittsmodus (Greenfield versus Akquisition) türkischer MNU für ihre Tochtergesellschaften in Rumänien, basierend auf einer Reihe von ausgewählten Fallstudien, untersucht. Unter Einbezug qualitativer Daten aus semistrukturierten Interviews, zeigt diese Studie, dass eine einzige Perspektive nur inadäquat die Eigentums- und Eintrittsmodusstrategien der türkischen MNU für ihre Tochtergesellschaften in Rumänien erklären kann.

Key words: Emerging countries, foreign direct investment, ownership mode, entry mode, Turkey, Romania (JEL: F21, G32)

\footnotetext{
* Manuscript received: 10.09.12, accepted: 18.12 .13 (2 revisions)

** Ibrahim Anil, Ph.D., Faculty of Economics and Administrative Sciences, Marmara University, Istanbul, Turkey. Main research interests: Turkish outward FDI activity, relationship between diversification strategies to organizational performance. E-mail: ianil@marmara.edu.tr

Ekrem Tatoglu, Ph.D., Chair of International Business and Trade, Faculty of Economics and Administrative Sciences, Bahcesehir University, Istanbul, Turkey. Main research interests: global management strategies, FDI in emerging countries, international entry mode strategies. E-mail: ekrem.tatoglu@bahcesehir.edu.tr (correspondence address)

Gaye Ozkasap, MBA, Faculty of Business, Istanbul University, Istanbul, Turkey. Main research interests: international entry and ownership modes strategies, organizational theories, corporate governance. E-mail: ozkasapgy@hotmail.com
} 


\section{Introduction}

Recently, multinational enterprises from emerging countries (EC MNEs) are regarded as the new power houses of foreign direct investment (FDI). Although MNEs from developed countries account for the majority of global outward FDI, EC MNEs have also shown an unprecedented growth in the value of outward FDI. According to World Investment Report 2011, the amount of outward FDI from emerging and transition countries reached a record level of $\$ 388$ billion in 2010 comprising about $29 \%$ of worldwide outward flows (UNCTAD 2011). As of 2012, there exist a total of 121 corporations from emerging and transition countries within the world's 500 largest global corporations (Fortune Global 500 2012).

Despite this growing FDI activity by EC MNEs, there is a scant research attention on the growing participation of emerging and transition country firms in global business and their impact on global competition. Although there is a rich array of research on internationalization and international market entry mode choice of developed country MNEs (DC MNEs) (see Brouthers and Hennart (2007) for a detailed review), there is relatively little research on the FDI activity of EC MNEs either in other emerging or transition countries (Erdilek 2008; Demirbag et al. 2009; Chiao et al. 2010; Anil et al. 2011). Existing studies on EC MNEs has so far focused on determinants of Chinese outward FDI (Buckley et al. 2007; Yiu et al. 2007), governance (Filatotchev et al. 2007) and location choice (Chen 1998; Yeung 1999; Al-Kaabi et al. 2010; Demirbag et al. 2010).

There is, however, an on-going debate on the internationalization of EC MNEs in the extant international business (IB) research. Recently, Luo and Tung (2007) offers a "springboard perspective" suggesting that EC MNEs internationalize by acquiring critical assets and capabilities abroad that they may lack to successfully compete on a global stage. Some scholars, however, oppose to this view arguing that EC MNEs have similarities to DC MNEs in that they have distinct sets of country and firm specific advantages (Ramamurti 2012; Narula 2012). Finally, some scholars posit that EC MNEs may internationalize in order to avoid from dire conditions in their home country markets or to pursue opportunities in an entrepreneurial fashion (Khanna/Palepu 2010; Madhok/Keyhani 2012). Indeed, compared with DC MNEs, EC MNEs have certain disadvantages stemming mainly from their less efficient home country institutional environment and lack of firm-specific advantages (see Cuervo-Cazurra/Genc (2008) for a detailed review). Despite these disadvantages, EC MNEs can have even more superior performance than DC MNEs especially in other emerging countries, as their abilities to manage in highly turbulent and difficult institutional home country environments may provide them with some clear advantages in similar business environments. Hence, they become leading investors in those countries. This view constitutes the central focus of this study in that suffering from the disadvantages of having a home country with "institutional voids" (Khanna/ 
Palepu 2000) may provide EC MNEs with a competitive edge abroad and also influence their foreign entry and ownership strategies (Meyer/Estrin 2001). In fact, a better understanding of where EC MNEs can be more successful is crucial for managers and can also improve their host country location strategies. Drawing on empirical data of seven case studies, this study essentially addresses the following two key questions: (1) To what extent the existing theoretical perspectives underlining IB research, explain ownership and entry mode choices of Turkish MNEs in a transition country, Romania? (2) How do managers of Turkish MNEs deal with the idiosyncrasies of Romanian market based on their relative advantages and disadvantages?

The choice of these two country contexts is of important contribution to existing research on this field. First, being a transition country, Romania provides an interesting survey setting, since the transition process provides a series of distinctive societal quasi-experiments (Meyer/Peng 2005). Even among emerging countries, transition countries are unique due to their radical switch from command economy to market competition and thus have been subject to a growing research interest for examining existing IB theories, where they are as yet insufficiently understood (Uhlenbruck/De Castro 2000; Hoskisson et al. 2000; Meyer/Estrin 2001; Nakos/Brouthers 2002; Gorynia et al. 2007). Although transition countries are considered as rapidly growing emerging country economies (Hoskisson et al. 2000), there is still a paucity of research in terms of entry and ownership mode choice of MNEs especially those from emerging countries. Hence, this survey allows us to capture some of the first steps of Turkish MNEs in their internationalization path. According to Meyer and Peng (2005), the core competencies that allow foreign investors to attain a sustainable competitive advantage in transition countries are likely different from those of DC MNEs, and a key challenge lies in identifying them. Among those resources that might be most important for foreign investors form emerging countries are flexibility, tacit knowledge, top management attitudes and experience, and low cost capabilities (Hoskisson et al. 2000; Uhlenbruck et al. 2003; Meyer/Peng 2005). The emerging nature of both countries' markets and the transitional characteristics of their institutional environments provide a good case to shed light on the main determinants of EC MNEs' ownership and market entry mode strategies in their subsidiaries in other emerging or transition countries. Moreover, from a theoretical standpoint, the evidence provided by our case study reveals about the adequacy or inadequacy of mainstream IB theories and perspectives with respect to strategic behaviour of EC MNEs.

The remainder of the study is organized as follows. The next section provides a review of existing theoretical perspectives with regard to ownership and entry mode choices of MNEs. Research methods are presented in Section 3. Findings and discussion are provided in Section 4. Conclusion and implications are set out in the final section. 


\section{Review of theoretical perspectives}

Recently, the rise of EC MNEs as global players in their respective industries is becoming a major phenomenon and has led to a growing interest in IB literature. Since mainstream theories were based largely on the analysis and observation of the behaviour and internationalization process of DC MNEs, there has been a debate about whether or not these existing theories may also explain the internationalization path of EC MNEs. While some scholars posit that these theories can easily explain EC MNE activity (Dunning et al. 2008), others suggest that new theoretical perspectives are called for EC MNEs as they tend to behave differently from their developed country counterparts (Mathews 2006; Luo/Tung 2007; Xu/Meyer 2012). On the other hand, some scholars have positioned themselves somewhere in between these two contrasting views, and suggest that these existing theories be extended to EC MNEs (Child/Rodrigues 2005; Cuervo-Cazurra 2012; Narula 2012; Ramamurti 2012; Meyer/Thaijongrak 2013).

Regarding EC MNEs, it is argued that the unique conditions of their home country environments influence their behaviour and internationalization path (Cuervo-Cazurra 2012; Luo/Wang 2012; Peng 2012). In this sense, Cuervo-Cazurra (2012) claims that the home country context tends to create an important impact on the strategic behaviour of EC MNEs noting that when the influence of the home country context declines, the assumptions of existing theoretical perspectives will be adequate in explaining the internationalization process of EC MNEs. Similarly, Ramamurti (2012) states that there is less difference between the behaviours of EC MNEs and those of DC MNEs than it has been thought, and this difference stems mainly from the home country conditions of EC MNEs. Moreover, Narula (2012) argues that at the earlier stages of internationalization, the firm-specific assets of EC MNEs reflect the country-specific assets of their home country (i.e. the conditions and constraints); but, as the EC MNEs evolve, the influence of the home country-specific assets on EC MNEs will decline, so will the differences between DC MNEs and EC MNEs.

\subsection{Ownership and entry mode choice}

In this study, we specifically focus on the ownership and entry modes of EC MNEs in their affiliates, and examine whether the mainstream theories that are essentially developed from studying DC MNEs can also explain the ownership and entry mode choices of EC MNEs in a transition country. Ownership and entry mode choice of foreign investors in their affiliates has been one of the central themes in the field of IB. A firm that intends to invest in a foreign country has to choose between two related but distinct strategic issues. First, it has to choose between non-equity entry modes, such as exporting and licensing, and equitybased entry modes, with either full ownership, i.e., a wholly owned subsidiary (WOS), or shared ownership, i.e., a joint venture (JV). Each of these modes varies significantly in terms of resource commitment and risk, with equity-based 
ownership modes involving the highest level of control. Following the choice of entering a foreign country market by either full or shared ownership modes, next decision is related to the entry mode which involves to acquire an existing domestic firm (acquisition) or to establish a new venture (greenfield investment). In the extant literature, the former is called as the ownership mode choice, while the latter is known as the entry (or establishment) mode choice.

The distinction between JV and WOS has been evaluated as a matter of equity control (Yiu/Makino 2002:667). As JV involves sharing joint control and ownership over the use of assets by two or more firms (Kogut/Singh 1988:412), WOS allows an MNE to keep the control and ownership of assets alone (Tsai/Cheng 2004). On the other hand, while greenfield refers to building a new facility from scratch, acquisition refers to buying out an already existing local firm (Hennart/Park 1993:1054). Each ownership and entry mode choices have their own advantages and disadvantages. Regarding ownership mode, a JV allows minimizing investment risk and exploiting valuable resources of a local partner, but it may also pose serious management problems due to partners' distinct values, interests and goals. Conversely, a WOS enables full control and ownership over the subsidiary, yet it must also cope with the liability of foreignness (Dikova/Witteloostuijn 2007:1015). As for entry mode choice, while an acquisition offers immediate and direct entry into foreign market, it may involve post-acquisition problems in terms of cultural misfits. Unlike an acquisition, a greenfield investment is a less risky option regarding the management of the venture, though it suffers from the longevity of investment which requires ample time to establish a new facility and to establish local business networks. In addition, Meyer and Estrin (2001) present a special form of an acquisition and label this entry mode "brownfield" as a hybrid mode of entry, which is somewhat peculiar to emerging country markets. The authors state that in emerging countries, "many investments, which are formally an acquisition, in fact resemble greenfield" since an acquired firm requires so extensive and radical restructuring where from the outset its resources and capabilities are primarily provided by the foreign investor replacing most of the resources and capabilities of the acquired firm (Meyer/Estrin 2001:576-577). Imperfect institutional framework and weak resource bases lead to high transaction costs in emerging country markets; therefore, brownfield is considered an attractive alternative if greenfield/acquisition is not feasible, or too costly, and if acquired firm's resources are necessary but not sufficient for investor (Meyer/Estrin 2001).

Compared with research on the MNE's choice of ownership of its foreign affiliates (Anderson/Gatignon 1986; Padmanabhan/Cho 1996; Delios/Beamish 1999; Makino/Neupert 2000; Yiu/Makino 2002), there has been relatively limited empirical work on the choice between acquisitions and greenfield investments (Hennart/Park 1993; Barkema/Vermeulen 1998; Brouthers/Brouthers 2000; Demirbag et al. 2008). It should also be acknowledged that there is no well- 
developed theoretical perspective concerning the strategic motivation for MNEs' ownership and entry mode choices of their foreign affiliates. Previous studies have investigated the influence of a number of variables that are relevant to these two distinct but related strategic choices, largely drawing on the basic premises of the transaction cost paradigm, institutional theory, the resourcebased view and the Dunning's eclectic approach. The four models identified here are not mutually exclusive and includes several overlapping arguments. It has been argued that using multiple perspectives would be more effective than a single perspective to explain the MNEs' ownership and entry strategies in emerging countries (Hoskisson et al. 2000; Luo 2001; Wright et al. 2005; Meyer/Peng 2005; Brouthers/Hennart 2007; Demirbag et al. 2009; Chiao et al. 2010), as the institutional contexts of these countries are more complex to explain by a single perspective (Peng/Heath 1996; Hoskisson et al. 2000; Hitt et al. 2000; Meyer 2001; Peng 2003; Wright et al. 2005; Meyer et al. 2009a). The intention, therefore, is to work within the context of prevailing theoretical views in explaining Turkish MNEs' ownership and entry mode strategies in Romania. The following subsections provide a brief review of these four most widely used theoretical perspectives on ownership and market entry mode choices MNEs.

\subsection{Transaction cost paradigm}

Transaction cost paradigm (TCP) has been heavily applied by researchers to explain the international entry and ownership mode choice of foreign investors (Brouthers/Hennart 2007). TCP addresses the entry and ownership modes of firms in terms of transaction costs and argues that firms prefer budget-friendly strategies which minimize transaction costs when investing abroad (Williamson 1985; Anderson/Gatignon 1986; Gatignon/Anderson 1988; Hennart/Park 1993; Erramilli/Rao 1993; Cho/Padmanabhan 1995; Yiu/Makino 2002; Brouthers et al. 2003; Tsai/Cheng 2004). TCP proposes a variety of factors, including both firmrelated and host country-related factors that may influence the benefits and costs associated with alternative entry and ownership modes. Relying on the TCP arguments, a foreign investor is likely to choose a JV mode when it needs complementary inputs, which would lead to high transaction costs. Conversely, when a foreign investor holds resources with high asset specificity, it will be more likely to choose a WOS over a JV (Hennart 1991). Regarding the entry mode choice, Hennart and Park (1993) posit that a foreign investor that has some firm-specific assets can exploit these assets abroad at low cost; and thus the level and nature of the firm-specific assets determine whether it will prefer greenfield or acquisition abroad. Brouthers and Hennart (2007) note that in most of the previous studies relying on TCP, a firm's R\&D intensity, which is a common measure of asset specificity, has been a key explanatory variable. That is, as the R\&D intensity of foreign investor is high, it is more likely to prefer a WOS rather than a JV so as to preserve these R\&D intensive assets against problems of opportunism and misuse (Gatignon/Anderson 1988; Padmanabhan/Cho 
1996; Delios/Beamish 1999; Makino/Neupert 2000; Luo 2001; Brouthers 2002; Tsai/Cheng 2004). In emerging countries, the diffusion of knowledge is an important problem since the weak institutional framework does not provide effective protection for intellectual proprietary rights. This will obviously lead foreign investors to choose a WOS mode as transaction costs will be substantially high with shared equity modes (Meyer 2001). Regarding this point, CuervoCazurra (2012) makes an important distinction between DC MNEs and EC MNEs in that EC MNEs are used to overcoming high transaction costs and poor contractual protections in their home country; therefore, when they expand abroad they tend to behave differently as compared to DC MNEs in dealing with transaction costs. Since EC MNEs have already learnt how to manage these transaction costs associated with poor institutional infrastructure in their home countries, this learning enables them to acquire capabilities to deal with these transactions costs, which in turn affect their choices of ownership and entry mode abroad. Erramilli and Rao (1993) argue that the relationship between asset specificity and ownership modes is moderated by numerous factors that either raise the costs of integration or diminish the foreign investor's ability to establish a WOS. Moreover, in a study that analyses the greenfield and acquisition choice of Japanese firms investing in the U.S., Hennart and Park (1993) indicate that R\&D-intensive Japanese investors prefer greenfield investment more highly than acquisitions as they perceive the greenfield mode as the most effective way of transferring their technological advantages to the U.S. shores. Similarly, Cho and Padmanabhan (1995) conclude that the preference for greenfield investment is also in line with foreign investor's strategy to transfer its organizational routines across its national frontiers to reduce costs. On the other hand, a firm with low R\&D intensity will prefer an acquisition mode to obtain complementary technology held by other firms (Cho/Padmanabhan 1995; Larimo 2003). In previous research, it is suggested that external uncertainty/country risk moderates the effect of asset specificity on the choice of ownership mode (Anderson/Gatignon 1986; Gatignon/Anderson 1988; Erramilli/Rao 1993). Erramilli and Rao (1993) state that the JV/WOS choice by firms with low- and high-asset specificity can be expected to differ minimally in low-risk countries but substantially in high-risk countries.

Another widely used TCP-related firm-level variable is the level of foreign investor's experience in a host country or in an international setting. Foreign investors with host country/international experience are better placed to undertake managerial responsibility and risks pertaining to WOS (Padmanabhan/Cho 1996). Such firms have also fewer disadvantages for gaining access to local market knowledge. So, they will be less likely to require a local partner to overcome these disadvantages (Dikova/Witteloostuijn 2007) and will tend to establish a WOS rather than a JV (Gatignon/Anderson 1988; Delios/Beamish 1999; Tsai/Cheng 2004). Regarding entry mode choice, a foreign investor without host country/international experience may need to choose an acquisition mode in or- 
der to obtain the capability and knowledge regarding local market (Wilson 1980) and to reduce the level of risk regarding international operations (Zejan 1990). Conversely, Kogut and Singh (1988) note that a foreign investor with international experience prefers acquisition because it can better undertake the risk of acquisition. Further, Larimo (2003) argues that foreign investors with international experience have the specific knowledge of managing and integrating new subsidiaries, while firms with host country experience have the specific knowledge of determining and evaluating potential acquisition candidates and negotiating with them; therefore, the foreign investors with host country/international experience will tend to choose acquisition (Demirbag et al. 2008). On the other hand, some research reveals that firms with host country/international experience prefer greenfield rather than acquisition due to the fact that they have the capabilities of overcoming the local environmental uncertainties or that they assume greenfield is an easier way to transfer abroad their well-established organizational routines (Wilson 1980; Brouthers/Brouthers 2000), while in some studies no meaningful relationship is noted between host country/international experience and acquisition/greenfield choice (Zejan 1990; Cho/Padmanabhan 1995; Larimo 2003; Anil et al. 2011).

The diversified entry is another variable which has been investigated in previous research relying on TCP. Hennart (1991) argues that foreign investor entering a host country market to manufacture a product that is outside of its main line of business may find that necessary product-specific knowledge is held or possessed by local firm. Such knowledge is most efficiently obtained through a JV, as this knowledge is difficult to be acquired by contract or is costly to replicate. A number of studies have shown that foreign market entries in a new line of business are more likely to be associated with JV as the most efficient way of reducing high transaction costs (Hennart 1991; Cleeve 1997; Demirbag et al. 2009). On the other hand, some studies note that the diversified entry of the foreign firm has no effect on the probability of sharing the ownership of its affiliate (Gomes-Casseres 1989; Hennart/Larimo 1998; Padmanabhan/Cho 1999). Regarding entry mode choice, previous research reveals that a firm entering a foreign market to manufacture a product that is outside of its main business is more likely to adopt acquisition mode to capture product specific knowledge which is difficult and costly to obtain from the market (Hennart/Park 1993; Brouthers/ Brouthers 2000; Larimo 2003). Conversely, Harzing (2002) does not find any significant relationship between entry mode and parent firm's diversification. Additionally, Hennart and Park (1993) argue that diversified firms have sophisticated management control systems which can be exploited through foreign acquisition; therefore, diversified firms are more likely to prefer acquisitions than greenfield investments in order to minimize transaction costs and improve efficiency. Some empirical support is found in previous research for the argument that the more diversified firms are more likely to enter foreign market through 
acquisition (Wilson 1980; Yip 1982; Zejan 1990; Larimo 2003; Demirbag et al. 2008).

\subsection{Institutional perspective}

Institutional perspective has recently emerged as an alternative approach to explain both ownership and entry mode choices of foreign investors in host country markets. Extending the TCP approach by adding the institutional dimension, this theory draws its logic from the argument that different environments are endowed with different levels of resources and institutions of varying effectiveness (Wan/Hoskisson 2003). The development level of the host country's institutional framework, which specifies "the rules of the game" (North 1990), has a significant influence on firm strategies and outcomes including ownership (Meyer 2001; Peng 2003; Peng/Zhou 2005; Meyer et al. 2009a) and entry mode decisions (Gomes-Casseres 1989; 1990; Cho/Padmanabhan 1995; Padmanabhan/ Cho 1996; Demirbag et al. 2008). Ingram and Silverman (2002) argue that in fact, the institutional context of a host country is much more than background circumstances as it determines the foreign investors' competitive strategies directly. In a similar vein, Chiao et al. (2010) indicate that the perceived institutional differences between an investing firm's home and host country have a moderating effect on the firm's ownership mode choice.

Peng and Heath (1996) suggest that network strategies are more appropriate for foreign investors which operate in unstable, ambiguous and restricting environments. Additionally, Peng and Luo (2000) posit that in uncertain and turbulent environments, securing personal ties and networks with top managers at other firms and also with government officials become highly crucial for a superior firm performance. In another study by Peng (2003), it is suggested that when the regulatory environment is unpredictable in a country, foreign investors are more likely to choose JV than WOS. However, Meyer et al. (2009a) note that foreign investors are less likely to use JVs in emerging host countries where institutions support market strongly.

Additionally, legal restrictions imposed by host country governments influence the ownership and entry mode decisions of foreign investors, enforcing them to prefer JV over WOS (Gatignon/Anderson 1988; Gomes-Casseres 1989; Padmanabhan/Cho 1996; Delios/Beamish 1999; Brouthers 2002). With regard to market entry modes, Cho and Padmanabhan (1995) and Larimo (2003) reveal that while firms investing in developed countries choose acquisition, those investing in emerging countries opt for greenfield since well-established acquisition candidates may be more available and foreign investors may face less legal restrictions in acquisitions within developed countries as compared to emerging countries. However, Meyer and Estrin (2001) argue that foreign investors in emerging countries may favour acquisitions if they want to enter the market 
quickly, as bureaucratic procedures with regard to greenfield investments are often more costly and time consuming.

Another institution specific influence on ownership and entry mode choice is associated with host country risk or uncertainty (Gatignon/Anderson 1988; Kim/Hwang 1992; Erramilli/Rao 1993; Delios/Beamish 1999; Luo 2001; Brouthers et al. 2002; Al-Kaabi et al. 2010). Host country risk or uncertainty is identified as the unpredictability of a firm's environment in which it operates (Anderson/Gatignon 1986) and as the extent to which this environment threatens the stability of the commercial activities of the firm (Gatignon/Anderson 1988). With regard to this issue, Yiu and Makino (2002) state that under the conditions of uncertainty, foreign investors prefer appropriate ownership modes to gain legitimacy in the relevant environments. Previous research indicates that in host countries with high risk, foreign investors avoid establishing WOS and prefer JV instead in order to ensure flexibility and share risk (Gatignon/Anderson 1988; $\mathrm{Kim} /$ Hwang 1992; Luo 2001). Concerning this issue, however, it is argued that EC MNEs can be better at coping with investment risk than DC MNEs because they are used to the conditions of risky and uncertain environment in their home country. Therefore, these firms are more likely to choose high commitment modes over other modes with lower resource commitments (Cuervo-Cazurra 2012). Regarding the entry mode choice, Demirbag et al. (2008) note that foreign investors would prefer greenfield investments to acquisitions when perceived host country risk is high. The authors further state that in emerging countries, an acquired firm may need to be restructured to cope with organizational, managerial and cultural fit problems and the restructuring of this acquired firm may even be much costlier than greenfield investment.

The effects of cultural distance on the ownership and entry mode choice of foreign investors have also been heavily investigated in previous research relying on institutional theory. It has been generally found that foreign investors would be more likely to choose JV over WOS, as the cultural distance between home and host countries increases (Kogut/Singh 1988; Gatignon/Anderson 1988; Erramilli/Rao 1993; Meyer 2001; Tsai/Cheng 2004). Foreign investors may require complementary assets in terms of gaining access to local market knowledge and experience in order to succeed in a culturally distant host country. Such complementary assets can be obtained from local partner, which in turn drives foreign investors to prefer JV rather than WOS (Padmanabhan/Cho 1996; Hennart/Larimo 1998). In their comparative study of inward and outward FDI in Turkey, Anil et al. (2011) also note that when foreign investors have positive perception towards the similarity of local cultures and business practices, they prefer JV to WOS. However, Demirbag et al. (2009) fail to find any effect of the cultural distance on Turkish MNEs' ownership mode choice in host country markets. Concerning entry mode choice, foreign investors have been found to be more in favour of building greenfield investments than acquisitions when 
there is a high degree of cultural distance between home and host countries (Kogut/ Singh 1988; Chang/Rosenzweig 2001; Larimo 2003; Tsai/Cheng 2004). In acquisitions, high cultural distance may lead to severe communication problems and also inability to transfer capabilities into the acquired firm (Meyer/Estrin 2001). In a similar vein, Larimo (2003) notes that when cultural distance between the two countries is high, acquisition may be more difficult than green-field because there might be some misfits in terms of organizational culture and managerial practices within the acquired firm that already operates with an existing labour force. However, the effect of cultural distance on entry mode choice is somewhat mixed as some studies have failed to find support for its impact on entry mode choice (Cho/Padmanabhan 1995; Brouthers/Brouthers 2000).

\subsection{Resource-based view}

Resource-based view (RBV) focuses on the resources and capabilities of a firm. The firm resources that are valuable, rare, faultily imitable and non-substitutable provide competitive advantages to firms (Barney 1991). According to RBV, firms expand abroad with the purpose of either exploiting their existing resources and capabilities in foreign markets or acquiring and exploring new resources and capabilities that provide them with competitive advantages (Makino et al. 2002; Luo 2002; Brouthers et al. 2008; Meyer et al. 2009b); therefore, the foreign investor's choices of ownership and entry mode abroad depend on whether and to what degree it requires such resources to gain competitive advantage (Meyer et al. 2009a). With regard to this issue, Demirbag et al. (2008) argue that if a foreign investor has more resource-based advantages than local firms, a greenfield investment enables the firm to preserve its resources and knowledge more than acquisition and also makes efficient knowledge transfer between parent and subsidiary possible. On the other hand, when a firm enters a foreign country in order to access local skills and resources, a JV or an acquisition would be preferred (Chang/Rosenzweig 2001). As to obtaining local knowledge, Anand and Delios (1997) argue that foreign investors may consider acquisitions to be less efficient than JVs owing to integration problems and high cost; however, in some cases where local partners are unavailable, acquisitions may represent the only viable option. In recent studies, it is stated that among EC MNEs, acquisitions are used as a primary mode of entry into host countries (Deng 2009; Peng 2012; Sun et al. 2012). For instance, Deng (2009) notes that Chinese MNEs predominantly opt for acquisition in order to reach and acquire strategic assets in their overseas investments. Similarly, Sun et al. (2012) propose that EC MNEs prefer acquisitions to gain "comparative ownership advantage" integrating technical, organizational and managerial resources across country-levels and firm-levels. Additionally, Luo and Tung (2007) argue that EC MNEs use international expansion as a springboard to acquire strategic re- 
sources; reduce the constraints of their home country; and turn their latecomer disadvantage into advantage.

Linking RBV with institutional theory, Meyer et al. (2009a) argue that in different institutional contexts, foreign investors that intend to explore new resources prefer different ownership and entry modes. In addition, they note that in a stronger institutional environment, acquisitions are used to access resources that provide competitive advantages, whereas JVs are more appropriate to access many local resources in a weaker institutional environment due to higher costs of acquiring local firms.

In their study of selecting JV partners in emerging and developed country markets, Hitt et al. (2000) reveal that firms from emerging countries place more emphasis on financial assets, technical capabilities, intangible assets and willingness to share expertise, whereas firms from developed countries attach more importance to the unique competencies access to local market knowledge. In a similar vein, Tatoglu and Glaister (2000) examine the main strategic motives for international JV formation between Western partner firms and local partner firms in Turkey. They find that when Western and Turkish firms formed JVs, Western firms are mainly concerned with gaining faster access to Turkish market and protection against potential risks of doing business in Turkey; whereas Turkish firms are essentially concerned with transferring technology and enabling high quality production so as to cope with intensive domestic competition.

In emerging and transition countries, where institutional framework is weak, forming networks and personal ties with government officials and top managers of other firms may be regarded as important and valuable assets which provide foreign investors with competitive advantages owing to fact that the networks and personal ties are heterogeneous and immobile (Peng/Heath 1996; Peng/Luo 2000; Peng 2003; Meyer et al. 2009a).

Anand and Delios (2002) argue that the preferences for entry mode are partially shaped by the relative technological advantages of home and host countries. When a host country has the relative technological advantage, a foreign investor is more likely to choose an acquisition, whereas it will tend to choose a greenfield investment when the home country has the relative technological advantage. Additionally, Barkema and Vermeulen (1998) posit that foreign investors with superior technological competencies and advantages have a strong preference for a greenfield investment for two reasons: firstly, existing local firms have relatively little technological competencies to offer foreign investors with stronger technological competencies; secondly, if the acquiring firm has superior technological competencies, the transfer of these competencies to the acquired firm may be difficult or impossible due to organizational inertia. On the other hand, a WOS is preferred over a JV when there is a risk of erosion in the value of a firm's technological assets (Madhok 1997); a finding which is con- 
sistent with that of Ekeledo and Sivakumar (2004) who reveal that firms with technological competencies are more likely to prefer a WOS mode in order to preserve their competitive advantages.

According to RBV, a firm's international/host country experience is considered as a firm-specific resource which provides firm with competitive advantage (Ekeledo/Sivakumar 2004; Claver/Quer 2005; Brouthers et al. 2008; Meyer et al. 2009b), while TCP considers a firm's host country experience as a factor reducing transaction costs. Ekeledo and Sivakumar (2004) note that firms with higher level of international experience prefer WOS mode when entering foreign countries. Regarding entry mode choice, Barkema and Vermeulen (1998) emphasise that firms with local experience prefer acquisition.

Previous research relying on the arguments of RBV considers firm size as a sign of competitive advantage in terms of financial, physical, human, technological or organizational resources (Larimo 2003; Ekeledo/Sivakumar 2004; Demirbag et al. 2009; Chiao et al. 2010). In fact, large size firms are perceived to have greater advantages in overcoming the risks and costs related to their investments (Terpstra/Yu 1988) and they tend to prefer WOS to JV (Brouthers et al. 1996; Elango/Sambharya 2004; Demirbag et al. 2009; Chiao et al. 2010). As to entry mode, the impact of firm size on entry mode choice is, however, unclear. While it has been posited that large firms have great financial resources to enter foreign markets through acquisitions (Kogut/Singh 1988; Chang/Rosenzweig 2001; Larimo 2003), some scholars argue that they would tend to prefer greenfield investments thanks to their greater resources available to overcome direct entry barriers (Yip 1982:337). Even in some other studies, no any significant relationship is found between the size of the firm and the entry mode choice (Chang/ Rosenzweig 2001; Demirbag et al. 2008).

In previous studies relying on RBV, the diversified entry has been identified and tested as one of the predictors of entry and ownership mode choices of foreign investors (Chatterjee 1990; Barkema/Vermeulen 1998; Chang/Rosenzweig 2001; Meyer et al. 2009b; Lee/Lieberman 2010). A foreign investor driven mainly by resource-seeking motives may sometimes enter a host country market in a new line of business outside of its main line of business. Chang and Rosenzweig (2001) argue that when an investor intends to enter a foreign market in a new line of business, it will obtain required expertise and skills from indigenous firms either through acquisition or by means of a shared equity investment. In a similar vein, Meyer et al. (2009b) posit that firms diversified across industries are more likely to employ resource-augmenting entry modes (i.e., JV and acquisition). Barkema and Vermeulen (1998) find that firms expanding abroad into related industries (horizontal, related, and vertical expansions) are more likely to choose greenfield in order to exploit their existing technological routines, while firms expanding into unrelated industries will be more in favour of acquisition in order to capture the needed capabilities. Similarly, Chatterjee (1990) notes that if 
an entered industry is related to the main business of the investing firm, greenfield is likely to be more favoured than an acquisition mode. Additionally, Lee and Lieberman (2010) find that outside a firm's primary business domain, if the new product market is less related to the firm's existing product, the acquisition is more likely to be preferred as an entry mode.

In recent studies with regard to EC MNEs, it is explained that EC MNEs have different ownership/firm-specific advantages than DC MNEs, reflecting the distinctive condition of their home countries. These advantages enable them to invest in foreign markets (Ramamurti 2012). Though the lack of sophisticated technological, marketing or managerial capabilities, EC MNEs have some valuable capabilities/advantages developed in their home country, such as projectexecution, political and networking skills, which form basis for their internationalization (Guillen/Garcia-Canal 2009). Additionally, Cuervo-Cazurra and Genc (2008) assert that since these firms have gained the ability to manage difficult institutional conditions in their home country, they may have an edge over their developed country counterparts in the countries which present similar problems and difficult institutional conditions, such as political instability, government ineffectiveness, poor regulatory quality, inefficient judicial system and the existence of corruption. In addition, Ramamurti (2009) states that these countryspecific disadvantages turn into firm-specific advantages when they are exploited in other emerging countries. However, he also adds that as the challenging conditions get better in these markets and DC MNEs become more experienced, the value of these advantages may shrink. Moreover, Cuervo-Cazurra (2012) argues that EC MNEs are more likely to prefer possessing higher control in their overseas affiliates because of their desire to protect ownership advantages and their distrust of weak institutional infrastructure. Hence, they tend to opt for WOS as ownership mode of their affiliates in host country markets.

\subsection{Dunning's eclectic framework}

Another stream of research derives from the application of Dunning's eclectic (OLI) approach (1988). It is the most widely used theoretical perspective explaining ownership and market entry mode choice of MNEs (Agarwal/Ramaswami 1992; Brouthers et al. 1996; 1999; Tatoglu/Glaister 1998a; Nakos/Brouthers 2002; Erdilek 2008, Demirbag et al. 2009). Dunning (1988) argues that firms choose the most appropriate form by appraising their ownership advantages $(\mathrm{O})$, the location advantages $(\mathrm{L})$ of host countries and the internalization advantages (I) while entering foreign country markets. Dunning's eclectic approach can be conceptualized as a tool that integrates insights from RBV (ownership advantages), institutional theory (location advantages) and transaction cost (internalization advantages) perspectives (Brouthers/Hennart 2007). In his recent work, Dunning extends the eclectic approach by integrating the institutional perspective (Dunning/Lundan 2008). However, unlike institutional theo- 
ry, location advantages of Dunning's eclectic approach also include "the Ricardian-type endowments which mainly comprise raw materials, most kind of labour, and proximity to markets" (Tatoglu/Glaister 1998a:286). Additionally, the market potential of a host country (size and growth) and the level of competition in a host country market have also been subsumed under the location advantages. Previous studies reveal that when either market potential is high or the level of competition is low, foreign investors are more likely to prefer WOS than JV because they are not willing to share potential success with another firm (Agarwal/Ramaswami 1992; Brouthers et al. 1996; 1999; Tatoglu/Glaister 1998a; Nakos/Brouthers 2002).

Relying on Dunning's eclectic approach, scholars generally investigate determinants of firms' ownership choice related to various market entry modes ranging from independent (licensing, franchising, agency/distribution, and contracting) and cooperative (JV) to integrated (WOS) modes. Existing research based on Dunning's eclectic approach indicates that foreign investors perceiving higher level of ownership, location and internalization advantages prefer integrated modes (WOS) (Brouthers et al. 1996; 1999; Tatoglu/Glaister 1998a; Nakos/ Brouthers 2002). In their survey of Western MNEs' FDI in Turkey, Tatoglu and Glaister (1998b) find that market size, repatriability of profits, the growth rate of Turkish economy and government policy towards FDI are the most important location advantages identified by Western MNEs. Despite plethora of research on ownership mode choice of foreign investors, Dunning's eclectic approach has not been fully applied to entry mode choice.

It should be borne in mind that the transition from overall theoretical perspective to the determinants of ownership and entry mode choice of foreign investors is not a straightforward one, as the theoretical approaches do not map neatly on to determinants. However, we are able to relate individual theoretical perspectives to the determinants of entry and ownership mode choice of foreign investors and thus to test the theories, indirectly at least. This is embodied in Tables 1 and 2. Table 1 classifies the key determinants of ownership and entry mode choices of foreign investors according to their theoretical roots. Table 2 sets out in detail the key determinants which make up an approximation to the theoretical explanation. To reiterate, the determinants do not map neatly on to theory. The determinants implied are not pure or perfectly distinct. We should remember that theory builders are mainly concerned with issues other than the firm's decision to choose a particular mode of ownership and entry. 
Table 1: Determinants of ownership and entry mode and theoretical explanation

\begin{tabular}{|l|c|}
\hline Key determinants & Theoretical explanation \\
\hline Host country risk/uncertainty & IP, TCP, OLI \\
\hline Cultural distance between home and host countries & IP, OLI, [TCP] \\
\hline R\&D intensity/asset specificity & TCP, [OLI] \\
\hline International/host country experience & RBV, OLI, TCP \\
\hline Firm-specific resources & RBV, OLI \\
\hline Firm size & RBV, TCP, OLI \\
\hline Diversified entry & RBV, TCP, [OLI] \\
\hline Market potential & OLI \\
\hline Legal restrictions imposed by host country & IP, OLI \\
\hline Competition in host country & OLI, [TCP], [IP] \\
\hline $\begin{array}{l}\text { Ricardian-type endowments (e.g. natural resources, labour and } \\
\text { proximity to markets) }\end{array}$ & OLI \\
\hline
\end{tabular}

\section{Notes:}

$\mathrm{TCP}=$ Transaction cost paradigm; IP = Institutional perspective; RBV = Resource-based view; OLI = Dunning's eclectic framework.

Bracketed terms [ ] - secondary

Table 2: Theoretical explanation and determinants of ownership and entry mode

1. Transaction cost paradigm - Implied determinants

Host country risk/uncertainty

R\&D intensity/asset specificity

International/host country experience

Diversified entry

Firm size

[Cultural distance between home and host countries]

[Competition in host country]

2. Institutional perspective - Implied determinants

Legal restrictions imposed by host country

Host country risk/uncertainty

Cultural distance between home and host countries

[Competition in host country]

3. Resource-based view - Implied determinants

Firm-specific resources

Firm size

International/host country experience

Diversified entry 


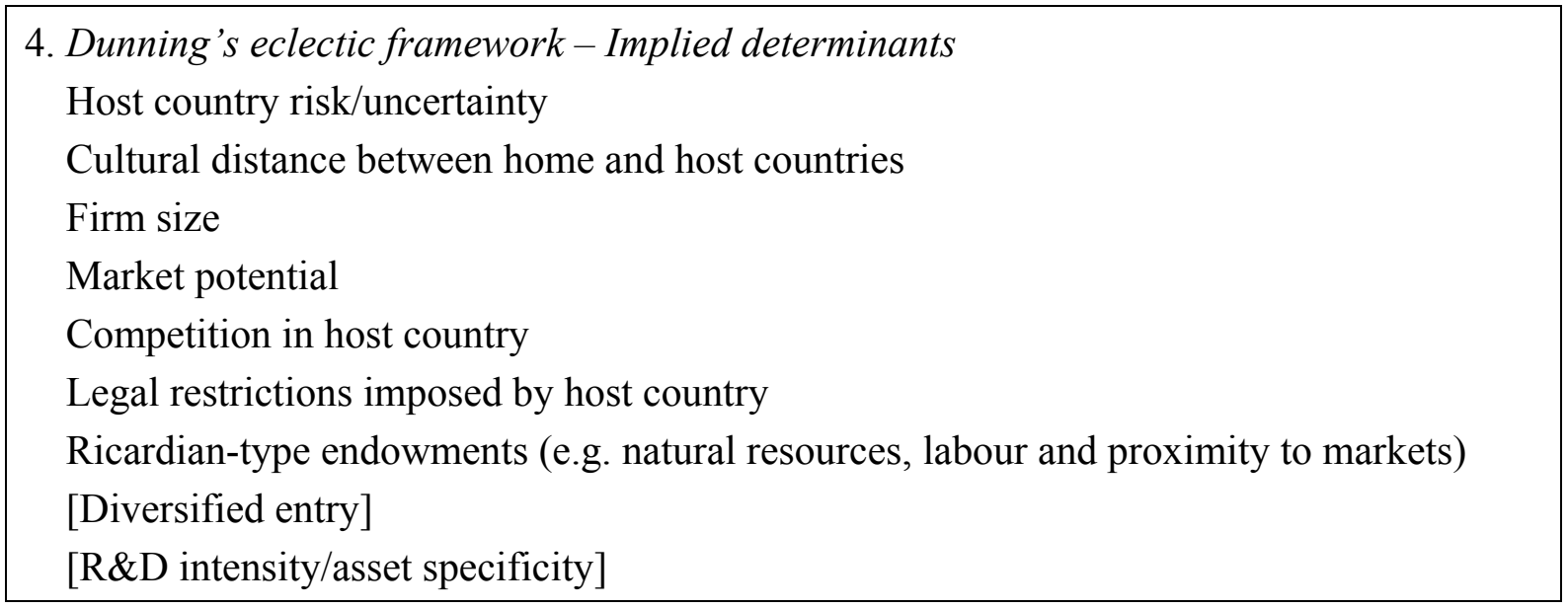

Note:

Bracketed terms [ ] - secondary

\section{Research methods}

In qualitative research, the adoption of case study method is seemingly more valuable to have a better understanding of the phenomena that take place within rich contexts (Johnston et al. 1999). To this end, a qualitative approach relying on the analysis of selected multiple case studies is adopted as the evidence from multiple case studies are considered more compelling and robust.

Case studies are based on analytical generalization rather than statistical generalization and the researchers attempt to generalize findings to a theory (Yin 1989). Therefore, this method provides us with an opportunity to acquire in-depth knowledge about the entry and ownership mode choices of Turkish MNEs in Romania, and also examines whether the empirical findings can be generalized to the existing theoretical perspectives reviewed earlier.

Case studies can be designed either single or multiple cases. In multiple-case studies, two or more cases are evaluated within the same study, and multiplecase studies are conducted with replication logic (Yin 1989). In a multiple-case study, the aim of the researcher is to gather the theory-supporting evidence from each case (Johnston et al. 1999). This study is designed as a multiple-case study which is based on the analyses of seven cases on the same phenomenon and conducted with replication logic.

The following subsections explain in detail the research setting, procedures for data gathering and analysis, validity and reliability of the method, and also description of the cases used in the study.

\subsection{Research setting}

The emerging nature of Romanian market and the transitional characteristics of its institutional environment, as well as trade and investment relations between Turkey and Romania influenced our choice of this country as the research setting. Over the past two decades, a growing trend has been observed in Turkey's 
outward FDI. There were nearly 150 outward FDI operations with a total value of $\$ 1,150$ million until 1990, with sharp increases observed in both the number and the value of outward FDI activity since then. Drawing on the official statistics, as of October 2010 the number of outward FDI entries reached 3,491 with the value of cumulative outward FDI totalling nearly $\$ 23.6$ billion (Republic of Turkey - Ministry of Economy 2012). Turkey is also one of the four major emerging country investors in transition countries along with China, India and South Korea (UNCTAD 2011:66). Romania has been one of the important transition countries in Central and Eastern Europe (CEE) which has been undergoing a dramatic transformation since the collapse of Communism in 1989 (Miron/ Paul 2010). Since becoming the member of European Union (EU) and NATO, Romanian institutional framework has been increasingly stable and provides lucrative market opportunities for foreign investors. It is the 7th largest market in EU with over 21 million inhabitants (Romania Trade \& Invest 2012). With its attractive location situated at the turning point between EU, the Balkans and CIS countries, Romania provides a unique market gateway to EU. Commensurate with these developments, trade and investment relations between Turkey and Romania have developed strongly for the past decade. The volume of foreign trade between Turkey and Romania has increased sharply up from $\$ 1 \mathrm{bn}$. in 2000 to 7.68 bn. in 2011. Turkey ranks 4th in terms of Romania's total export revenues and features as 7th in terms of its imports (Republic of Turkey - Ministry of Economy 2012). In the same period, Turkish FDI in Romania has increased dramatically now featuring 11th with a value of $\$ 625$ million in terms of the total stock of FDI, while Turkey ranks 3rd in Romania regarding the number of foreign investors indicating that majority of Turkish investors are composed of small and medium size firms (IGEME 2011). FDI statistics regarding Turkey, however, are misleading as most of the Turkish FDI inflows to Romania have been through indirect FDI (Kalotay 2012) via the utilization of intermediaries in other countries such as the Netherlands.

\subsection{Data gathering and analysis}

Initially, we designed a "study protocol" that describes the procedures with regard to the selection of cases, the content of interview guide, the method of data collection and analysis. The selection of cases was made on the basis of the parent size and the sector of operation. In this study, we only focused on Turkish MNEs' subsidiaries operating in the manufacturing sector, excluding those in services as the latter group of firms responds differently to some specific variables and thus, their entry mode choices are very different from each other (Brouthers/Brouthers 2003). After carefully screening Turkish MNEs operating in Romania, a total of eleven large size Turkish MNEs were chosen as suitable case studies. A warm-up letter with an interview guide was posted to the CEO of each firm requesting that the $\mathrm{CEO}$, or his/her senior executive with relevant 
knowledge, should participate in our survey. Following the initial contacts with these firms, a total of seven accepted our invitation to take part in our survey.

To seek answers to our research questions, data was derived from semi-structured interviews with company executives, who participated in implementation process of the strategic decisions concerning their investment in Romania. We prepared an interview guide which was composed of two main parts including a total of 15 questions. The first part of the interview questions were related to information about the general characteristics of both parent firm (e.g. field of activities, their investments in other countries, number of employees) and those of its affiliate in Romania (e.g. date of entry, ownership mode, entry mode, industry of affiliate, number of employees in the affiliate). The second part of the interview guide involved questions related to understanding and identifying the main factors which were effective on their decisions to choose from particular entry and ownership modes.

The participants were all senior level executives whose positions ranged from general/deputy manager to board chairman/member. The interviews were conducted in each respondent's office during the period of March-June in 2010. The durations of interviews ranged between 45 and 60 minutes. The questions to the interviewees were all asked in an unbiased conversational manner to collect more reliable data. The responses to the interview questions were tape-recorded and transcribed into main interview theme categories corresponding to the determinants of the theoretical perspectives. In order to explore to what extent the data fit to the main theme categories, we analysed the data from each case individually and discussed each one afterwards. We then examined the similarities and differences across the cases in terms of each category corresponding to the underlying determinants of the theoretical perspectives, which would influence choices of the firms' entry and ownership modes. The semi-structured interviews were also accompanied by relevant data collected from a wide variety of sources including internal company documents (e.g., annual reports, memos and company handbooks), company websites, business media and industry reports to cross-verify and improve reliability (Yin 1989).

\subsection{Validity and reliability}

With regard to the validity and reliability of case study method, we adopted the framework developed by Gibbert et al. (2008:1467) to investigate methodological rigor of case studies. Following this framework, we tried to establish the reliability and validity of our case study approach. Internal validity was attested by a comprehensive literature review and applying the premises of four mainstream theoretical perspectives that have been widely used in similar other studies. Construct validity was established by means of data triangulations (interview data accompanied by secondary data), review of the transcripts and draft by the responding executives, and also through clear explanation of the data analysis 
process. Moreover, the data were analysed via providing clear chain of evidence in the ensuing subsections of findings and discussion. External validity was enabled by adopting multiple-case study approach drawing on a sample of seven different firms on the same subject, and also explaining clearly the rationale for the selection of this approach. Finally, reliability was achieved by explaining the case study protocol, revealing the identity of the sample firms and also providing their detailed descriptions.

\subsection{Description of cases}

In this study, the data was drawn from the following seven Turkish firms, which constituted the sample of this study: Kastamonu Entegre, Pakmaya, Ulker, DYO, Superlit, Kombassan Group, and Erdemir. Detailed descriptions regarding these seven firms were provided in Appendix. Table 3 shows the positions of executives interviewed, dates of entry, ownership modes and entry modes of their affiliates.

Table 3: Characteristics of cases

\begin{tabular}{|l|l|c|c|c|c|}
\hline Firms & $\begin{array}{l}\text { Executives intervie- } \\
\text { wed }\end{array}$ & $\begin{array}{c}\text { Date of } \\
\text { entry }\end{array}$ & $\begin{array}{c}\text { Number } \\
\text { of } \\
\text { employees }\end{array}$ & $\begin{array}{c}\text { Ownership } \\
\text { mode }\end{array}$ & Entry mode \\
\hline Pakmaya & Board Member & 1994 & 200 & WOS & Greenfield \\
\hline K. Entegre & $\begin{array}{l}\text { Deputy General } \\
\text { Manager }\end{array}$ & 1998 & 600 & WOS & Brownfield \\
\hline Kombassan & General Coordinator & 2000 & 2000 & WOS & Acquisition \\
\hline Ulker & $\begin{array}{l}\text { Deputy General } \\
\text { Manager/Operations }\end{array}$ & 2002 & 263 & WOS & Greenfield \\
\hline Erdemir & $\begin{array}{l}\text { Chairman of the } \\
\text { Board }\end{array}$ & 2002 & 350 & WOS & Acquisition \\
\hline DYO & $\begin{array}{l}\text { Foreign Investments } \\
\text { Director }\end{array}$ & 2003 & 41 & JV & Brownfield \\
\hline Superlit & General Manager & 2006 & 90 & JV & Greenfield \\
\hline
\end{tabular}

Three of these seven firms, which included Pakmaya, Ulker and Superlit, entered the Romanian market through greenfield investment mode. The other four sample firms, which involved DYO, Kastamonu Entegre, Kombassan Group and Erdemir, entered Romania through acquisition. Of these entries, Kastamonu Entegre's and DYO's investments are formally an acquisition, though they resemble more to a greenfield investment. With regard to DYO's entry mode, the Foreign Investments Director at DYO stated that "We bought out of an existing manufacturing plant. This plant did not have any manufacturing machinery and equipment, and we built a new full-fledged manufacturing facility from the outset. We purchased the plant at a low price to acquire its building plot along with 
its essential infrastructure from the Romanian Government through the privatization of state-owned enterprises. We were not aware of whether the plant was still operational at that time." Similarly, the Deputy General Manager at Kastamonu Entegre clarified that "We initially acquired the manufacturing facility through the privatization of state-owned enterprises. It was a lumber plant with essential infrastructure and railway, and we purchased it at low price. We did not utilize its existing manufacturing machinery and equipment. The whole plant was completely restructured ranging from manufacturing to labour and product line within two years." Since the acquired firms were subject to deep restructuring, and in fact resembled greenfield, these acquisitions were considered as brownfield in this study, as suggested by Meyer and Estrin (2001).

Regarding the ownership mode of their investments, five of the seven firms including Kastamonu Entegre, Erdemir, Pakmaya, Ulker and Kombassan Group preferred WOS mode rather than JV mode. The remaining two investors, Superlit and DYO adopted to enter the Romanian market through JV mode. Superlit established a JV with a partner who was formerly a member of the Senate in Romania and who held $40 \%$ of the total equity share. DYO entered the Romanian market by engaging in an equal ownership JV with a Turkish paint marketer.

\section{Findings and discussion}

\subsection{Transaction cost paradigm}

According to the arguments of TCP, WOS and greenfield modes are preferred by foreign investors with high asset-specificity/R\&D intensity when there is a higher likelihood of deterioration in the product quality and greater risk of R\&D specific information leakage. Additionally, foreign investors are likely to choose $\mathrm{JV}$ and acquisition modes when they need complementary inputs, which may obviously lead to high transaction costs if they are purchased from the market (Hennart 1991; Hennart/Park 1993). The executives of all sample firms admit that in Romania, there is a dissemination risk of product information and also risk of being exposed to problems of opportunism due to inadequate laws and regulations and also weak judicial processes. The Foreign Investments Director at DYO stated that "In Romania, the courts have been functioning very slowly, the conclusion of the lawsuits has taken very long time, and the ineffectiveness of the courts has been a huge problem. While it is a member of EU, it has still been undergoing transition process." The responding executives at both Pakmaya and Ulker confirmed these arguments by preferring WOS and greenfield modes as these two investing firms are characterized by high $R \& D$ intensity. Similarly, Kastamonu Entegre which also operates in a high R\&D intensive industry preferred WOS mode as an ownership structure of its affiliate, while its method of entry to Romanian market was more of a brownfield; therefore Kastamonu Entegre's investment tends to support these arguments. Although 
Erdemir also adopted a WOS mode as ownership structure of its affiliate, it preferred acquisition rather than greenfield investment as a market entry mode despite its high asset specificity/R\&D intensity. The Chairman of the Board at Erdemir explained that "...this is because the acquired firm had siliceous steel production know-how which was very costly to obtain directly from the market". Therefore, this acquisition helped Erdemir reduce its transaction costs by attaining this proprietary technology cheaply. This investment tends to support the TCP argument that acquisition is preferred to obtain complementary technology held by another firm if this technology would be much costlier to purchase from the market (Hennart/Park 1993; Cho/Padmanabhan 1995; Larimo 2003). DYO and Superlit, which are characterized by high R\&D intensity, prove to be in line with the TCP arguments by choosing brownfield and greenfield mode, respectively. In terms of ownership mode choice, The General Manager at Superlit expressed that "We preferred a JV partner, who was formerly a member of the Senate in Romania, with the aim of easing bureaucratic procedures and also utilizing the partner's networks regarding the greenfield investment process". The Foreign Investments Director at DYO explained that "We established a JV with a paint marketer to obtain the knowledge of gaining access to the local market". Although they operate in R\&D intensive industries, these two firms' preferences for JV would confirm the relevant argument related to mitigating the transaction costs associated with such industries (Hennart 1991). However, the responding executive at DYO indicated that "We did not take host country related risks into account when we formed JV. We tended to avoid the dissemination risk of proprietary knowledge by holding our partner responsible for only marketing activities and not involving him in manufacturing processes". Concerning this issue, the responding executive at Superlit made a very similar explanation "We did not consider these risks in our decision to choose JV as we did not involve our partner in manufacturing processes. We intended only to utilize his networks and personal ties with government officials. He was responsible for marketing activities and bureaucratic procedures". Therefore, these two firms had some protection against these risks and problems by taking appropriate managerial actions. These statements are in line with the argument of Cuervo-Cazurra (2012) who claims that since EC MNEs are generally used to have high transaction costs and poor contractual protections in their home country, they have learnt how to manage these transaction costs and how to secure themselves against inefficient judicial system; therefore, they respond differently to transaction costs as compared to their developed country counterparts.

Kombassan Group, which is a highly diversified company, entered Romania through acquisition and WOS mode. The General Coordinator at Kombassan Group stated that "We acquired Rulmenti bearings plant at a bargain price through the privatization of state-owned enterprises. This bearings plant had superior technological resources and capabilities. If we set up such an investment from scratch, it would be impossible or very costly for us. Acquiring this bear- 
ings plant, we entered to an entirely different market, which was very profitable, but with no any resemblance to our main line of business." The Kombassan Group's decision for this acquisition might be construed as a clear reflection of its unrelated diversification strategy. Driven solely by financial purposes, Kombassan Group utilized its excessive capital to fund its acquisitions at bargain prices in Romania. Gaining access to an entirely different market also helped Kombassan Group pursue its multinational diversification strategy. In this respect, Erdemir's choice of an acquisition mode could also be considered as a delineation of its related diversification strategy. The Chairman of the Board at Erdemir emphasized that "This acquisition is the part of our financial strategy with the intention of pursuing speculative gains by using our surplus capital. We acquired a facility at a bargain price due to its chronic efficiency problems. We have been successfully operating in iron and steel industry. Acquiring this facility, we obtained siliceous steel production know-how, which Erdemir did not have and which could provide us with competitive edge". Previous research reveals that a firm entering a foreign market to manufacture a product that is outside of its main business prefers acquisition to capture product specific knowledge which is difficult and costly to obtain from the market (Hennart/Park 1993; Brouthers/Brouthers 2000; Larimo 2003). The entry mode choices of Kombassan Group and Erdemir are in line with the findings of these studies. Moreover, some empirical support has been found for the argument that more diversified firms have sophisticated management control systems which could be exploited through foreign acquisition; therefore, they prefer acquisitions in order to minimize transaction costs and improve efficiency (Wilson 1980; Yip 1982; Zejan 1990; Larimo 2003; Demirbag et al. 2008). As a highly diversified company, Kombassan Group also tends to support this argument by entering Romania through acquisition. With regard to ownership mode choice, a number of studies have shown that foreign market entries in a new line of business are more likely to be associated with JV as the most efficient way of reducing high transaction costs (Hennart 1991; Cleeve 1997; Demirbag et al. 2009). On the other hand, some scholars noted that the diversity of parent firm had no effect on the probability of its choice for a JV (Gomes-Casseres 1989; Hennart/Larimo 1998; Padmanabhan/Cho 1999). In this study, both Kombassan Group and Erdemir were found to be more in favour of a WOS and not willing to share the ownership of their affiliates through a JV.

Another well-known argument of TCP is related to the level of firm's host country/international experience that has an influence on a foreign investor's choice of ownership and entry mode (Padmanabhan/Cho 1996; Delios/Beamish 1999; Brouthers/Brouthers 2000; Tsai/Cheng 2004; Dikova/Witteloostuijn 2007). All sample firms, with the exception of Ulker, revealed that their investment in Romania were their first FDI operation, although they initially exported their products to several different countries including Romania. The Deputy General Manager at Ulker explained that "While we had some experience regarding both ex- 
porting and FDI to several different countries, prior to our investment in Romania, our international and host country experience did not have a direct effect on entry and ownership mode choices in Romania". Similarly, the executives of other sample firms mentioned that although their prior host country/international experience had some influence on their FDI decisions, it did not have a direct influence on their decisions to choose a particular ownership and entry mode. These findings tend to be line with those of previous studies (Zejan 1990; Cho/ Padmanabhan 1995; Larimo 2003; Anil et al. 2011).

\subsection{Institutional perspective}

Institutional perspective posits that when host country risk or uncertainty is high, foreign investors are likely to establish a JV with a local partner in order to ensure flexibility and share risk (Gatignon/Anderson 1988; Kim/Hwang 1992; Luo 2001). In addition, when perceived host country risk is high, foreign investors may prefer greenfield investment to acquisition due to potential costs associated with acquisitions (Demirbag et al. 2008). Until 2005 when Romania was acceded to the EU, the country was among the countries considered as risky by global investors. At present, the responding executives of the sample firms except Superlit acknowledged that Romania would no longer pose serious business risks to foreign investors. Even at the time of their investment, they did not consider the impact of host county risks on their ownership and entry mode choice. As regards this issue, the Deputy General Manager at Kastamonu Entegre said that "There was political instability at that time, and now there is too, for example head of privatization department were replaced twelve times within ten years. The political instability caused delays regarding our investments; of course, the country was risky, but the risk was not that much high for us and we did not take the host county risk into account in our preferences regarding the ownership and entry mode of our investments". Similarly, the Board Member at Pakmaya said that, "We knew that Romania had just changed its regime and we were aware of the disturbance, to which the regime change gave rise. There was some risk, but there was chance too. Additionally, it was the risk which could be worth taking for us. However, the risk did not have any particular effect on our choices of entry and ownership mode". The Foreign Investments Director at DYO expressed that "Romania had been undergoing transition process, when we made our investment. However, Romania was not that much risky...we were one of the first movers in our industry sector; generally, the investors from Europe started to enter Romania after 2005. I think we, Turkish investors, are more entrepreneurial." This view might be partially explained by Turkish investors' readiness to take host country related risks as they have developed shrewd ways of coping with the uncertainties and risks of their domestic market for so long. This finding is also consistent with the arguments of Cuervo-Cazurra (2012) and CuervoCazurra and Genc (2008) that EC MNEs can be better at coping with risks than their developed country counterparts in host countries with difficult institutional 
conditions because they are used to cope with institutional voids in their home country. On the other hand, the General Manager at Superlit stated that "Romanian business environment was risky and the risk influenced our choice of ownership mode. Therefore, we preferred to establish a JV with a local partner, who was an influential businessman and a former member of the Romanian Senate. We considered that the partner would be of immense help to ease the bureaucratic procedures regarding our greenfield investment process and also to forge links with local business networks and government officials in Romania". This is precursor to the success of foreign investors operating in emerging or transition countries, because several of their clients are essentially state-held companies.

Another view shared by all responding executives of our sample firms was that they were affiliated with one or more business associations because it was known that these business associations play an active role in creating networks, providing information and lobbying activities. The Board Member at Pakmaya, stated that "An investment cannot be made without having strong personal ties and engaging in networks at the global level. At the time of our investment, as the environmental uncertainty was high in Romania, these personal ties and networks were much more important; therefore, we took the advantage of them especially in fulfilling our greenfield investment procedures". Similarly, the General Coordinator at Kombassan Group stated that "We have been affiliated with several associations. We especially utilized their connections with the government regarding our debt restructuring in the crisis period." This finding is in line with those of Peng and Heath (1996), and Peng and Luo (2000) who suggest that network strategies are very crucial for the performance of foreign investors in emerging country markets. Additionally, all sample firms reported that none of them encountered any limitations imposed by the Romanian Government with respect to ownership and entry modes.

Another important variable related to institutional theory is the cultural distance between home and host countries, which is envisaged to influence foreign investors' decision to choose a particular ownership or entry mode for their affiliates. It was revealed that even though all sample firms were aware of the cultural differences between the two countries, these differences did not affect their entry and ownership choices. With regard to this issue, the Foreign Investments Director at DYO said that "There are no any cultural similarities between the two countries. Although the religion, language, lifestyle, and business practices are all different between Romania and Turkey, these cultural differences did not affect our choices of entry and ownership modes." This finding tends to confirm the results of previous studies (Cho/Padmanabhan 1995; Brouthers/Brouthers 2000; Demirbag et al. 2009). Nevertheless, the responding executives stated that in order to cope with the cultural misfits and overcome communication problems, Romanian employees were appointed to some important managerial positions at different departments within the subsidiaries ranging from sales and 
marketing to human resources. Employees were also provided with essential training and development to avoid problems that might stem from differences in work practices and managerial values between the two cultures.

\subsection{Resource-based view}

Resource-based view postulates that when a foreign investor has more resourcebased advantages than a local firm, it is more likely to prefer WOS and greenfield investment in order to better exploit its resources that provide competitive advantage (Madhok 1997; Demirbag et al. 2008). On the other hand, it will tend to choose acquisition or JV if it intends to gain access to local labour and resources to enhance its competitive advantage (Chang/Rosenzweig 2001; Meyer et al. 2009a; 2009b).

In this study, both Pakmaya and Ulker intended to utilize their resource-based advantages by choosing WOS and greenfield modes. Ownership and entry mode choices of Kastamonu Entegre are also in line with the above RBV arguments. The ownership mode choice of both DYO and Superlit towards establishing JV with a local partner in order to utilize its local market knowledge and networks also provides some support for the RBV. In a similar vein, Erdemir's acquisition of a domestic steel manufacturer to obtain its siliceous steel production knowhow may also be taken as an attempt towards the same direction.

Some studies relying on RBV posit that firms expanding abroad with resourceseeking motives may invest in industry sectors outside of their main line of business. Diversified firms are more likely to prefer JV or acquisition so as to obtain required expertise and skills (Chang/Rosenzweig 2001; Meyer et al. 2009b). In Romania, Kombassan Group expanded into an unrelated industry; therefore, its choice of acquisition is driven mainly by RBV logic. On the other hand, Erdemir's expansion into related industry by acquiring the Romanian facility with siliceous steel production know-how to gain access to this proprietary technology also provides some support for the arguments of RBV. Erdemir's choice of acquisition is, however, contrary to the finding of Barkema and Vermeulen (1998) who note that firms expanding abroad into related industries (horizontal, related, and vertical expansions) are more likely to choose greenfield.

Another argument of RBV is related to the size of the parent firm and views it as a sign of competitive advantage. Large firms tend to prefer WOS since they have greater advantages in overcoming the risks and costs related to their investments (Brouthers et al. 1996; Elango/Sambharya 2004; Demirbag et al. 2009; Chiao et al. 2010). In this study, all sample firms are relatively large and all of the responding executives admitted that the size of their firms influenced their ownership mode choices. This argument has been confirmed by five of the sample firms with the exceptions of DYO and Superlit which chose to establish JV. Although both DYO and Superlit are relatively large, their preferences to- 
wards a JV mode were influenced by other factors. Concerning this issue, the Deputy General Manager at Ulker said that "Ulker is a financially strong firm; therefore, we preferred WOS rather than a JV." With regard to entry mode, some researches were unable to find any significant relationship between the firm's size and the entry mode (Chang/Rosenzweig 2001; Demirbag et al. 2008). In this study, all the executives acknowledged that the size of their firms influenced their greenfield/acquisition choices. Regarding this issue, the Board Member at Pakmaya emphasized that "We have had adequate financial resources to undertake the greenfield investment." On the other hand, the General Coordinator at Kombassan Group stated that "We have great financial resources to acquire the firm." Therefore, it should be noted that the net effect of firm size regarding greenfield/acquisition is not clear as evident in our sample firms, which is also consistent with the findings of previous research (Chang/Rosenzweig 2001; Demirbag et al. 2008).

\subsection{Dunning's eclectic paradigm}

As noted earlier, Dunning's eclectic approach is a holistic view that integrates insights from resource-based (ownership advantages), institutional (location advantages), and transaction cost (internalization advantages) perspectives (Brouthers/Hennart 2007). Most of the determinants analysed earlier can also be subsumed under Dunning's eclectic framework. To avoid duplication, only those that are not mentioned so far are considered. These include host country market potential, the level of industry competition in the host country market and the Ricardian-type endowments which might also be labelled as location specific attractions of the host country.

When either host country market potential is high or the extent of industry competition is low, foreign investors are more likely to be in favour of forming a WOS. Concerning the level of industry competition in Romanian market, the responding executives from Pakmaya, Ulker and Superlit mentioned that the competition was high but not so intensive. As for DYO, the competition was perceived as relatively weak in the market. Both Pakmaya and Ulker preferred WOS despite high level of industry competition, a finding which is again contrary to the view that when the extent of competition in the host country market is low, foreign investors should adopt a WOS mode. One possible explanation for this finding is that when the host country market potential is high, a foreign investor does not seriously consider the intensity of industry competition as it may have an assumption that it could surmount this hurdle by engaging in a direct investment to have a competitive edge over its rivals. On the other hand, the preferences of Superlit and DYO towards JV mode were influenced by other factors rather than the host country market potential and the level of industry competition as mentioned by responding executives from both firms. On the other hand, the Chairman of the Board at Erdemir said that "The market poten- 
tial was weak and the extent of competition was high. We preferred WOS because Erdemir generally would not be willing to share ownership with a partner". Again, as stated by company executives, these two factors did not also influence the choice of Kastamonu Entegre and Kombassan in favour of establishing WOS because their target market was not the Romanian market. Regarding this issue, the Deputy General Manager at Kastamonu Entegre stated that "Our target markets are Turkey and the other European countries, not Romania." And the General Coordinator at Kombassan Group added that "Romania has not been our target market, since over 90 per cent of our sales are generated outside Romania."

Moreover, other location specific motives that were cited as highly important by responding executives include: cheap raw materials and availability of qualified labour (Kastamonu Entegre and Pakmaya); availability of qualified and cheap labour (DYO and Kombassan); proximity of host country market to neighbouring country markets (the whole sample firms); having first-mover advantages (Pakmaya and DYO), the high probability of the then Romania to become a member of the EU (the whole sample firms). Although these motives were perceived as highly important by the responding sample firms to select Romania as a target market, it is unclear whether they had any direct influence on their choice of a particular ownership or market entry mode in their affiliates in Romania.

\section{Conclusion and implications}

This study has provided valuable information on ownership and market entry mode choices of investing firms from a key emerging country, Turkey when they entered in a transition country, Romania. Given the paucity of research on the FDI activity of EC MNEs in other emerging or transition countries, this study might be considered as an attempt to fill this lacuna. Additionally, most previous studies explaining either ownership or market entry mode choice of foreign investors in their affiliates relied heavily on a single theoretical perspective. It has been generally acknowledged that using multiple perspectives would prove more useful than relying on a single perspective to explain the MNE strategies in emerging countries due to distinctive characteristics of their institutional contexts. Drawing upon qualitative data from selected Turkish investors in Romania, this study relied on multiple perspectives to better identify the key determinants of ownership and entry mode choices of Turkish MNEs in their Romanian affiliates. It should however be borne in mind that these theoretical perspectives, which include transaction cost paradigm, institutional theory, resource-based view and Dunning's eclectic approach, are not mutually exclusive and includes several overlapping arguments.

The empirical findings drawn from our case study firms in general tend to confirm the view that the relative disadvantages of EC MNEs resulting mainly from 
having a home country with less efficient institutional infrastructure may then become a source of relative advantage when they serve other emerging country markets characterized by poor institutional environments (Cuervo-Cazurra/Genc 2008; Ramamurti 2009). In this study, it has been found that Turkish firms generally were more in favour of appropriate ownership and entry modes which would reduce transaction costs. In some instances, however, where there is high risk of dissemination of proprietary know-how or where problems of opportunism are highly likely, Turkish investors may choose to engage in a JV with a local partner in Romania, which is somewhat contrary to the general arguments of TCP approach. One possible explanation for this finding is that these firms have been exposed to similar conditions in their home country and they have developed several astute ways of dealing with these risks over the years (CuervoCazurra 2012). Surprisingly, it has also been found that Turkish investors generally did not perceive the host country environment as seriously risky, and their risk perception regarding host country did not have an obvious influence on their decision to choose a particular mode of entry and ownership. Hence, they do not consider these risks and their respective costs as highly serious especially when compared with foreign investors from developed countries. This might be partially explained by Turkish investors' readiness to take host country related risks as they have developed shrewd ways of coping with the uncertainties and risks of their domestic market for so long. These findings therefore are in line with those of previous research noting that the home country conditions of EC MNEs may influence their internationalization paths (Cuervo-Cazurra/Genc 2008; Cuervo-Cazurra 2012; Luo/Wang 2012; Peng 2012). Moreover, it can be asserted that the mainstream theories, that have been largely used to explain the internationalization process of DC MNEs, can be extended further by considering home country conditions of EC MNEs (Child/Rodrigues 2005; Cuervo-Cazurra 2012; Narula 2012; Ramamurti 2012). Another interesting finding is that neither the host country/international experience nor cultural distance had any direct influence on ownership and entry mode choices of Turkish investors. Thus, the relevant arguments of institutional theory may not be alone sufficient to explain the internationalization pattern of Turkish MNEs (Brouthers/ Brouthers 2000; Demirbag et al. 2009).

In the same vein, it has been found that generally Turkish investors entered Romania with the purpose of either exploiting their firm-specific resources and capabilities or acquiring and exploring new resources and capabilities which provide them with required competitive advantages. Their ownership and entry mode strategies were hence driven by the strategic motives of resource exploitation and exploration, which partially confirm the arguments of RBV (Makino et al. 2002; Luo 2002; Brouthers et al. 2008; Meyer et al. 2009b).

Among the various host country-specific location advantages, only the market potential of the host country were noted to have some impact on Turkish inves- 
tors' ownership strategy in Romania. The other location specific factors such as cost of inputs, availability of qualified labour and proximity to neighbouring country markets were all identified as highly important by Turkish investors only in their decision to choose Romania as an appropriate location for investment.

Finally, our study has revealed that a hybrid entry mode choice of brownfield has also been preferred by Turkish MNEs as an attractive alternative when greenfield/acquisition is not feasible or too costly in Romania. This finding provides some additional support to earlier research (e.g. Meyer/Estrin 2001) examining the entry mode strategies of foreign investors in CEE.

On the whole, the findings of this study may prove useful to better understand the strategic behaviour of other EC MNEs when they invest in other emerging or transition countries in CEE that tend to exhibit similar institutional characteristics with Romania.

\subsection{Managerial implications}

It is generally acknowledged that the choice of a particular ownership and entry mode for outward FDI is one of the most critical decisions that managers of several EC MNEs have to make. Within the context of mainstream theoretical perspectives explaining the strategic behaviour of EC MNEs on ownership and entry mode, it is assumed that several institutional, transaction specific and firm level variables may have a crucial influence on global competitiveness and, hence, long-term survival of numerous emerging country firms. EC MNEs, as late comers to global expansion, attempt to exploit their firm specific advantages (e.g., ability to develop locally responsive products, production and operational excellence) especially when investing in other emerging countries (Ramamurti 2009; Guillen/Garcia-Canal 2009). Unlike DC MNEs, EC MNEs benefit enormously from inward FDI at home by using different linkages such as joint venturing or original equipment manufacturing with global players that transmit technological and managerial skills, leading them to undertake their internationalization later in some unconventional ways (Child/Rodrigues 2005; Bonaglia et al. 2007; Li 2007; Luo/Tung 2007; Ramamurti 2009; Deng 2009; Yaprak/Karademir 2011; Luo/Wang 2012). For instance, Turkish MNEs have long engaged in joint ventures and OEM manufacturing as common initial strategies to mitigate risk and gain access to superior technological and managerial know-how of their foreign partners (Bonaglia et al. 2007; Yaprak/Karademir 2011). Following experiential learning and developing their own R\&D in their joint ventures, Turkish MNEs prefer to set up greenfield investment of acquiring full ownership of indigenous firms in emerging host countries. Turkish MNEs may also use global expansion through higher equity modes as a springboard to secure preferential treatment offered by host country governments and also to bypass trade barriers into developed country markets such as other European Union countries. It is therefore highly critical for EC MNEs to invest time and money in investi- 
gating as many factors as possible prior to the choice of a particular equity ownership and entry mode of their outward investments. In some circumstances, the wrong choice may obviously threaten the survival of the investing firm. EC MNEs should ensure that they concentrate on the factors that are most relevant to their own situation.

\subsection{Limitations and future research}

While this study offers some useful insights, caution should be exercised when interpreting the results. Perhaps the most serious limitation of this study stems from the case study approach. Being confined to a relatively small sample, it is difficult to generalize the findings to the entire population of MNEs emanating from emerging countries. While controlling for cross-country differences, the study's narrow focus on a single host country setting again precludes the generalization of findings. The sensitive nature of the subject and the availability of personal connections, however, have made the selection of case study methodology requisite over other large-scale quantitative surveys.

Future studies could obviously test the validity of the existing theoretical perspectives comparatively across various emerging country contexts. It would also be beneficial in future studies to deal with how EC MNEs' ownership and entry mode strategies co-evolve with changes in the institutional environment in other emerging countries. Nonetheless, the study' findings should be used as a basis for further deepened research with relatively larger data sets. Ours is one of the few attempts in uncovering some of the managerial mechanisms and processes through which EC MNEs take affirmative steps when choosing among alternative ownership and entry mode strategies in other emerging country contexts.

\section{Acknowledgements}

We would like to acknowledge the insightful comments of two anonymous reviewers and the Chief Editor of JEEMS, Professor Thomas Steger on earlier versions of this paper.

\section{References}

Agarwal, S./Ramaswami, S.N. (1992): Choice of foreign market entry mode: Impact of ownership, location and internalization factors, in: Journal of International Business Studies, 23, 1, 1-27.

Al-Kaabi, M./Demirbag, M./Tatoglu, E. (2010): International market entry strategies of emerging market MNEs: A case study of Qatar telecom, in: Journal of East-West Business, 16, 2, 146-170.

Anand, J./Delios, A. (1997): Location specificity and the transferability of downstream assets to foreign subsidiaries, in: Journal of International Business Studies, 28, 3, 579-603.

Anand, J./Delios, A. (2002): Absolute and relative resources as determinants of international acquisitions, in: Strategic Management Journal, 23, 2, 119-134. 
Anderson, E./Gatignon, H. (1986): Modes of foreign entry: A transaction cost analysis and propositions, in: Journal of International Business Studies, 17, 3, 1-26.

Anil, I./Cakir, O./Canel, C./Porterfield, R. (2011): A comparison of inward and outward foreign direct investment determinants in Turkey, in: International Journal of Business and Social Science, 2, 20, 141-155.

Barkema, H.G./Vermeulen, F. (1998): International expansion through start-up or acquisition: A learning perspective, in: Academy of Management Journal, 41, 1, 7-26.

Barney, J. (1991): Firm resources and sustained competitive advantage, in: Journal of Management, 17, 1, 99-120.

Bonaglia, F./Goldstein, A./Mathews, J.A. (2007): Accelerated internationalization by emerging markets' multinationals: The case of the white goods sector, in: Journal of World Business, 42, 4, 369-383.

Brouthers, K.D. (2002): Institutional, cultural and transaction cost influences on entry mode choice and performance, in: Journal of International Business Studies, 33, 2, 203-221.

Brouthers, K.D./Brouthers, L.E. (2000): Acquisition or greenfield start-up? Institutional, cultural and transaction cost influences, in: Strategic Management Journal, 21, 1, 89-97.

Brouthers, K.D./Brouthers, L.E. (2003): Why service and manufacturing entry mode choices differ: The influence of transaction cost factors, risk and trust, in: Journal of Management Studies, 40, 5, 1179-1204.

Brouthers, K.D./Brouthers, L.E./Werner, S. (1996): Dunning's eclectic theory and the smaller firm: The impact of ownership and locational advantages on the choice of entry-modes in the computer software industry, in: International Business Review, 5, 4, 377-394.

Brouthers, L.E./Brouthers, K.D./Werner, S. (1999): Is Dunning's eclectic framework descriptive or normative?, in: Journal of International Business Studies, 30, 4, 831-844.

Brouthers, K.D./Brouthers, L.E./Werner, S. (2002): Industrial sector, perceived environmental uncertainty and entry mode strategy, in: Journal of Business Research, 55, 6, 495-507.

Brouthers, K.D./Brouthers, L.E./Werner, S. (2003): Transaction cost-enhanced entry mode choices and firm performance, in: Strategic Management Journal, 24, 1239-1248.

Brouthers, K.D./Brouthers, L.E./Werner, S. (2008): Resource-based advantages in an international context, in: Journal of Management, 34, 2, 189-217.

Brouthers, K.D./Hennart, J.F. (2007): Boundaries of the firms: Insights from international entry mode research, in: Journal of Management, 33, 3, 395-425.

Buckley, P.J./Clegg, L.J./Cross, A.R./Liu, X./Voss, H./Zheng, P. (2007): The determinants of Chinese outward foreign direct investment, in: Journal of International Business Studies, 38, 4, 499-518.

Chang, S.J./Rosenzweig, P.M. (2001): The choice of entry mode in sequential foreign direct investment, in: Strategic Management Journal, 22, 8, 747-776.

Chatterjee, S. (1990): Excess resources, utilization costs, and mode of entry, in: Academy of Management Journal, 33, 4, 780-800.

Chen, T.J. (ed.) (1998): Taiwanese firms in Southeast Asia: Networking across borders. Cheltenham: Edward Elgar. 
Chiao, Y.C./Lo, F.Y./Yu, C.M. (2010): Choosing between wholly-owned subsidiaries and joint ventures of MNCs from an emerging market, in: International Marketing Review, $27,3,338-365$.

Child, J./Rodrigues, S.B. (2005): The internationalization of Chinese firms: A case for theoretical extension?, in: Management \& Organization Review, 1, 3, 381-410.

Cho, K.R./Padmanabhan, P. (1995): Acquisition versus new venture: The choice of foreign establishment mode by Japanese firms, in: Journal of International Management, 1, 3, 255-285.

Claver, E./Quer, D. (2005): Choice of market entry mode in China: The influence of firmspecific factors, in: Journal of General Management, 30, 3, 51-70.

Cleeve, E. (1997): The motives for joint ventures: A transaction costs analysis of Japanese MNEs in the UK, in: Scottish Journal of Political Economy, 44, 1, 31-43.

Cuervo-Cazurra, A. (2012): Extending theory by analyzing developing country multinational companies: Solving the goldilocks debate, in: Global Strategy Journal, 2, 3, 153-167.

Cuervo-Cazurra, A./Genc, M. (2008): Transforming disadvantages into advantages: Developing-country MNEs in the least developed countries, in: Journal of International Business Studies, 39, 6, 957-979.

Delios, A./Beamish, P.W. (1999): Ownership strategy of Japanese firms: Transactional, institutional and experience influences, in: Strategic Management Journal, 20, 10, 915-933.

Demirbag, M./Tatoglu, E./Glaister, K.W. (2008): Factors affecting perceptions of the choice between acquisition and greenfield entry: The case of western FDI in an emerging market, in: Management International Review, 48, 1, 5-38.

Demirbag, M./Tatoglu, E./Glaister, K.W. (2009): Equity-based entry modes of emerging country multinationals: Lessons from Turkey, in: Journal of World Business, 44, 4, 445-462.

Demirbag, M./Tatoglu, E./Glaister, K.W. (2010): Institutional and transaction cost determinants of Turkish MNEs' location choice, in: International Marketing Review, 27, 3, 272-294.

Deng, P. (2009): Why do Chinese firms tend to acquire strategic assets in international expansion?, in: Journal of World Business, 44, 1, 74-84.

Dikova, D./Witteloostuijn, A. van (2007): Foreign direct investment mode choice: Entry and establishment modes in transition economies, in: Journal of International Business Studies, 38, 6, 1013-1033.

Dunning, J.H. (1988): The eclectic paradigm of international production, in: Journal of International Business Studies, 19, 1, 1-31.

Dunning, J.H./Lundan, S.M. (2008): Multinational enterprises and the global economy, 2nd ed. Cheltenham: Edward Elgar.

Dunning, J.H./Kim, C./Park, D. (2008): Old wine in new bottles: A comparison of emergingmarket TNCs today and developed-country TNCs thirty years ago, in: Sauvant, K.P. (ed.): The rise of transnational corporations from emerging markets: Threat or opportunity?, Cheltenham: Edward Elgar, 158-179. 
Ekeledo, I./Sivakumar, K. (2004): International market entry mode strategies of manufacturing firms and service firms: A resource-based perspective, in: International Marketing Review, 21, 1, 68-101.

Elango, B./Sambharya, R.B. (2004): The influence of industry structure on the entry mode choice of overseas entrants in manufacturing industries, in: Journal of International Management, 10, 1, 107-124.

Erdilek, A. (2008): Internationalization of Turkish MNEs, in: Journal of Management Development, 27, 7, $744-760$.

Erramilli, M.K./Rao, C.P. (1993): Service firms' international entry-mode choice: A modified transaction-cost analysis approach, in: Journal of Marketing, 57, 3, 19-38.

Filatotchev, I./Strange, R./Piesse, J./Lien, Y.C. (2007): FDI by firms from newly industrialized economies in emerging markets: Corporate governance, entry mode and location, in: Journal of International Business Studies, 38, 4, 556-572.

Fortune Global 500 (2012): Global 500 2012: Annual ranking of the world's largest corporations, http://money.cnn.com/magazines/fortune/global500/ (accessed online 28th April 2013).

Gatignon, H./Anderson, E. (1988): The multinational corporation's degree of control over foreign subsidiaries: An empirical test of transaction cost explanation, in: Journal of Law, Economics \& Organization, 4, 2, 305-336.

Gibbert, M./Ruigrok, W./Wicki, B. (2008): What passes as a rigorous case study?, in: Strategic Management Journal, 29, 1465-1474.

Gomes-Casseres, B. (1989): Ownership structures of foreign subsidiaries, in: Journal of Economic Behavior \& Organization, 11, 1, 1-25.

Gomes-Casseres, B. (1990): Firm ownership preferences and host government restrictions: An integrated approach, in: Journal of International Business Studies, 21, 1, 1-22.

Gorynia, M./Howak, J./Wolniak, R. (2007): Motives and modes of FDI in Poland: An exploratory qualitative study, in: Journal for East European Management Studies, 12, 2, 132 151

Guillen, M.F./Garcia-Canal, E. (2009): The American model of the multinational firm and the 'new' multinationals from emerging economies, in: Academy of Management Perspectives, 23, 2, 23-35.

Harzing, A.W. (2002): Acquisitions versus greenfield investments: International strategy and management of entry modes, in: Strategic Management Journal, 23, 3, 211-227.

Hennart, J.F. (1991): The transaction costs theory of joint ventures: An empirical study of Japanese subsidiaries in the United States, in: Management Science, 37, 4, 483-497.

Hennart, J.F./Larimo, J. (1998): The impact of culture on the strategy of multinational enterprises: Does national origin affect ownership decisions?, in: Journal of International Business Studies, 29, 3, 515-538.

Hennart, J.F./Park, Y.R. (1993): Greenfield vs. acquisition: The strategy of Japanese investors in the United States, in: Management Science, 39, 9, 1054-1070.

Hitt, M.A./Dacin, M.T./Lewitas, E.J./Edhec, L.A./Borza, A. (2000): Partner selection in emerging and developed market contexts: Resource-based and organizational learning perspectives, in: Academy of Management Journal, 43, 3, 449-467. 
Hoskisson, R.E./Eden, L./Lau, C.M./Wright, M. (2000): Strategy in emerging economies, in: Academy of Management Journal, 43, 3, 249-267.

IGEME (2011): Romania, country report, Ankara: Republic of Turkey - Ministry of Economy.

Ingram, P./Silverman, B. (2002): Introduction, in: Ingram, P./Silverman, B. (eds.): The New Institutionalism in Strategic Management, Amsterdam: Elsevier, 1-30.

Johnston, W.J./Leach M.P./Liu, A.H. (1999): Theory testing using case studies in business-tobusiness research, in: Industrial Marketing Management, 28, 3, 201-213.

Kalotay, K. (2012): Indirect FDI, in: The Journal of World Investment \& Trade, 13, 4, 542555.

Kim, W.C./Hwang, P. (1992): Global strategy and multinationals' entry mode choice, in: Journal of International Business Studies, 23, 1, 29-53.

Khanna, T./Palepu, K. (2000): The future of business groups in emerging markets: Long-run evidence from Chile, in: Academy of Management Journal, 43, 3, 268-285.

Khanna, T./Palepu, K. (2010): Winning in emerging markets: A road map for strategy and execution. Cambridge: Harvard Business Press.

Kogut, B./Singh, H. (1988): The effect of national culture on the choice of entry mode, in: Journal of International Business Studies, 19, 3, 411-432.

Larimo, J. (2003): Form of investment by Nordic firms in world markets, in: Journal of Business Research, 56, 10, 791-803.

Lee, G.K./Lieberman, M.B. (2010): Acquisition vs. internal development as modes of market entry, in: Strategic Management Journal, 31, 2, 140-158.

Li, P.P. (2007): Toward an integrated theory of multinational evolution: The evidence of Chinese multinational enterprises as latecomers, in: Journal of International Management, $13,3,296-318$.

Luo, Y. (2001): Determinants of entry in an emerging economy: A multilevel approach, in: Journal of Management Studies, 38, 3, 443-472.

Luo, Y. (2002): Capability exploitation and building in a foreign market: Implications for multinational enterprises, in: Organization Science, 13, 1, 48-63.

Luo, Y./Tung, R.L. (2007): International expansion of emerging market enterprises: A springboard perspective, in: Journal of International Business Studies, 38, 4, 481-498.

Luo, Y./Wang, S.L. (2012): Foreign direct investment strategies by developing country multinationals: A diagnostic model for home country effects, in: Global Strategy Journal, 2, $3,244-261$.

Madhok, A. (1997): Cost, value and foreign market entry mode: The transaction and the firm, in: Strategic Management Journal, 18, 1, 39-61.

Madhok, A./Keyhani, M. (2012): Acquisitions as entrepreneurship: Asymmetries, opportunities, and the internationalization of multinationals from emerging economies, in: Global Strategy Journal, 2, 1, 26-40.

Makino, S./Lau, C.M./Yeh, R.S. (2002): Asset-exploitation versus asset-seeking: Implications for location choice of foreign direct investment from newly industrialized economies, in: Journal of International Business Studies, 33, 3, 403-421. 
Makino, S./Neupert, K.E. (2000): National culture, transaction costs, and the choice between joint venture and wholly owned subsidiary, in: Journal of International Business Studies, 31, 4, 705-713.

Mathews, J.A. (2006): Dragon multinationals: New players in 21 st century globalization, in: Asia Pacific Journal of Management, 23, 1, 5-27.

Meyer, K.E. (2001): Institutions, transaction costs and entry mode choice in Eastern Europe, in: Journal of International Business Studies, 32, 2, 357-367.

Meyer, K.E./Estrin, S. (2001): Brownfield entry in emerging markets, in: Journal of International Business Studies, 32, 3, 575-584.

Meyer, K.E./Peng, M.W. (2005): Probing theoretically into Central and Eastern Europe: Transactions, resources and institutions, in: Journal of International Business Studies, $36,6,600-621$.

Meyer, K.E./Estrin, S./Bhaumik, S.K/Peng, M.W. (2009a): Institutions, resources and entry strategies in emerging economies, in: Strategic Management Journal, 30, 1, 61-80.

Meyer, K.E./Wright, M./Pruthi, S. (2009b): Managing knowledge in foreign entry strategies: A resource-based analysis, in: Strategic Management Journal, 30, 5, 557-574.

Meyer, K.E./Thaijongrak, O. (2013): The dynamics of emerging economy MNEs: How the internationalization process model can guide future research, in: Asia Pacific Journal of Management, 30, 4, 1125-1153.

Miron, D./Paul, A. (2010): Liberalization and normality in the competition behavior: The case of the Romanian transition economy, in: Transformations in Business \& Economics, 19, 1 (Supplement A), 246-259.

Nakos, G./Brouthers, K.D. (2002): Entry mode choice of SME's in Central and Eastern Europe, in: Entrepreneurship Theory \& Practice, 27, 1, 47-63.

Narula, R. (2012): Do we need different frameworks to explain infant MNEs from developing countries?, in: Global Strategy Journal, 2, 3, 188-204.

North, D.C. (1990): Institutions, institutional change and economic performance. UK: Cambridge University Press.

Padmanabhan, P./Cho, K.R. (1996): Ownership strategy for a foreign affiliate: An empirical investigation of Japanese firms, in: Management International Review, 36, 1, 45-65.

Padmanabhan, P./Cho, K.R. (1999): Decision specific experience in foreign ownership and establishment strategies: Evidence from Japanese firms, in: Journal of International Business Studies, 30, 1, 25-44.

Peng, M.W. (2003): Institutional transitions and strategic choices, in: Academy of Management Review, 28, 2, 275-296.

Peng, M.W./Heath, P. (1996): The growth of the firm in planned economies in transition: Institutions, organizations and strategic choices, in: Academy of Management Review 21, 2, 492-528.

Peng, M.W./Luo, Y. (2000): Managerial ties and firm performance in a transition economy: The nature of a micro-macro link, in: Academy of Management Journal, 43, 3, 486501. 
Peng, M.W./Zhou, J.Q. (2005): How networks strategies and institutional transitions evolve in Asia, in: Asia Pacific Journal of Management, 22, 4, 321-336.

Peng, M.W. (2012): The global strategy of emerging multinationals from China, in: Global Strategy Journal, 2, 2, 97-107.

Ramamurti, R. (2009): What have we learned about emerging-market MNEs?, in: Ramamurti, R./Singh, J.V. (eds.): Emerging multinationals in emerging markets, Cambridge: Cambridge University Press, 399-426.

Ramamurti, R. (2012): What is really different about emerging market multinationals?, in: Global Strategy Journal, 2, 1, 41-47.

Republic of Turkey - Ministry of Economy (2012): Foreign trade statistics, www.ekonomi. gov.tr (accessed online 27 January 2012).

Romania Trade \& Invest (2012): Reasons to invest, http://www.romtradeinvest.ro/index.php (accessed online 29 January 2012).

Sun, S.L./Peng, M.W./Ren, B./Yan, D. (2012): A comparative ownership advantage framework for cross-border M\&As: The rise of Chinese and Indian MNEs, in: Journal of World Business, 47, 1, 4-16.

Tatoglu, E./Glaister, K.W. (1998a): Determinants of foreign direct investment in Turkey, in: Thunderbird International Business Review, 40, 3, 279-314.

Tatoglu, E./Glaister, K.W. (1998b): Western MNCs' FDI in Turkey: An analysis of location specific factors, in: Management International Review, 38, 2, 133-159.

Tatoglu, E./Glaister, K.W. (2000): Strategic motives and partner selection criteria in international joint ventures in Turkey, in: Journal of Global Marketing, 13, 3, 53-92.

Terpstra, V./Yu, C.M. (1988): Determinants of foreign investment of U.S. advertising agencies, in: Journal of International Business Studies, 19, 1, 33-46.

Tsai, M.T./Cheng, Y.M. (2004): Asset specificity, culture, experience, firm size and entry mode strategy: Taiwanese manufacturing firms in China, South-East Asia and Western Europe, in: International Journal of Commerce \& Management, 14, 3/4, 1-27.

Uhlenbruck, K./De Castro, J. (2000): Foreign acquisitions in Central and Eastern Europe: Outcomes of privatization in transition economies, in: Academy of Management Journal, 43, 3, 381-402.

Uhlenbruck, K./Meyer, K.E./Hitt, M. (2003): Organizational transformation in transition economies: Resource-based and organizational learning perspectives, in: Journal of Management Studies, 40, 2, 257-282.

UNCTAD (2011): World investment report 2011: Non-equity modes of international production and development, New York and Geneva: United Nations.

Wan, W.P./Hoskisson, R.E. (2003): Home country environments, corporate diversification strategies and firm performance, in: Academy of Management Journal, 46, 1, 27-45.

Williamson, O.E. (1985): The economic institutions of capitalism. New York: Basic Books.

Wilson, B.D. (1980): The propensity of multinational companies to expand through acquisitions, in: Journal of International Business Studies, 11, 1, 59-65. 
Wright, M./Filatotchev, I./Hoskisson, R.E./Peng, M.W. (2005): Guest editors' introduction: Strategy research in emerging economies: Challenging the conventional wisdom, in: Journal of Management Studies, 42, 1, 1-33.

$\mathrm{Xu}$, D./Meyer, K.E. (2012): Linking theory and context: Strategy research in emerging economies since Wright et al., in: Journal of Management Studies, 50, 7, 1322-1346.

Yaprak, A./Karademir, B. (2011): Emerging market multinationals' role in facilitating developed country multinationals' regional expansion: A critical review of the literature and Turkish MNC examples, in: Journal of World Business, 46, 4, 438-446.

Yeung, H.W.C. (1999): The globalization of business firms from emerging economies, Vol. 2, Cheltenham: Edward Elgar.

Yin, R.K. (1989): Case study research: Design and methods. London: Sage.

Yip, G.S. (1982): Diversification entry: Internal development versus acquisition, in: Strategic Management Journal, 3, 4, 331-345.

Yiu, D./Makino, S. (2002): The choice between joint venture and wholly owned subsidiary: An institutional perspective, in: Organization Science, 13, 6, 667-683.

Yiu, D./Lau, C.M./Bruton, G. (2007): International venturing by emerging economy firms: The effects of firm capabilities, home country networks and corporate entrepreneurship, in: Journal of International Business Studies, 38, 4, 519-540.

Zejan, M.C. (1990): New ventures or acquisitions: The choice of Swedish multinational enterprises, in: Journal of Industrial Economics, 38, 3, 349-355.

\section{Appendix: Case studies}

\section{Case 1: Pakmaya}

Pakmaya is one of the world's largest producers of yeast. Pakmaya belongs to Pak Holding operating in food, chemical, pharmaceutical and paper industries. Since the opening of the first Pakmaya plant near Istanbul in 1973, the company has grown rapidly becoming one of the world's major yeast producers. Pakmaya at present owns and operates three manufacturing plants in Turkey and one in Romania.

\section{Case 2: Kastamonu Entegre}

Kastamonu Entegre (Kastamonu Integrated Wood Industry and Trade Company) is one of the largest producers in the wood-based panels industry in Turkey. The company is producing raw and melamine particle board, raw and melamine mdf, laminate flooring, skirting, doorskin, and related value added products. Kastamonu Entegre is one of the subsidiaries of Hayat Holding, primarily operating in the chemicals and wood-based industry. Kastamonu Entegre has six plants in Turkey and three plants outside Turkey which were established in Romania, Bulgaria and Bosnia Herzegovina. 


\section{Case 3: Kombassan Group}

The Kombassan Group is active in a variety of sectors including paper and cardboard, machinery, oil, construction and building materials, marble, textiles, tourism and food. Kombassan Group acquired Rulmenti bearings plant in Romania in 2000. Rulmenti exports $80 \%$ of its production to 81 countries in the world. Kombassan Group has several plants in Turkey, but Rulmenti is the Group's only plant outside Turkey.

\section{Case 4: Ulker}

Ulker is the founding brand name and flagship company of Yildiz Group in the biscuit category of the food sector. Y1ld1z Holding was founded in 1944. The business activities of Yildız Holding take place in two main fields - food and non-food items. The most established business activities of Y1ldız Holding lie in the food industry and the company is most well-known as a food and beverages group. Additionally, Y1ldiz Holding is active in non-food business activities that include finance, packaging, real estate, retail, information technologies and personal care products. Y1ldiz Holding engaged in FDI in several countries including the U.S., Saudi Arabia, Kazakhstan, Ukraine, Egypt, Romania, Belgium and Pakistan. In Romania, it operates in manufacturing and sales of biscuits and salted crackers.

\section{Case 5: Erdemir}

Erdemir Group is the largest industrial corporation in Turkey in terms of value of its total assets and has a total of 9 subsidiaries. The group is one of the major players in iron and steel industry with industrial facilities in Turkey and Romania. It owns $80 \%$ of iron ore reserves in Turkey. Erdemir Romanya is located in Târgovişte, Romania and was acquired in 2002. The facility produces flat silicon steel for engine, transformer and generator sectors.

\section{Case 6: DYO}

DYO is the paint division of Yaşar Holding, which was founded in 1927. The other divisions of Yaşar Holding are food and beverages, trade and services, tissue paper, agriculture, livestock and fisheries. DYO has a large portfolio of paint products including construction paints, industrial paints, furniture paints, automotive paints, marine paints and printing inks. DYO has manufacturing subsidiaries in Romania, Russia and Egypt. The manufacturing plant of DYO in Romania produces paints for construction industry.

\section{Case 7: Superlit}

Superlit Boru Sanayi is the first company established by Karamanci Holding. It was founded in 1961. Superlit produces and sells pressurized/unpressurized pipes and currently continues its GRP (Fiberglass Reinforced Polyester) pipe 
production lines. The company is prominent with its large scale domestic and international sales activities along with its high quality manufacturing and wide product range. Superlit made its first FDI operation in Romania through establishing its Fiberglass Reinforced Polyester pipe factory based on "Continuous Filament Winding" technology. 